\title{
ECONOMICS OF FODDER AND SEED PRODUCTION OF IMPORTANT LEGUMINOUS COWPEA CROP
}

\author{
VIKAS KUMAR, D. BAHUKHANDI, VINOD K WASNIK \& M. SUMAN \\ ICAR-Indian Grassland and Fodder Research Institute, Jhansi Uttar Pradesh, India
}

Higher productions of both Cowpea fodder and cowpea seed are necessary for balance fodder supply and regular seed supply. Cowpea is an important leguminous fodder crop grown during summer and rainy season. It is demanded for its quick growing habit, high yielding ability and high protein content. The cost analysis of cowpea fodder (EC 4216) was done under the farmers' fields in 2011-12 and 2012-13 and cowpea seed production seed was done at IGFRI Jhansi with the commercial variety EC4216 in the year 2010-11 and 2012-13. The average per hectare total cost of cultivation incurred in cowpea fodder production was $R$ s 19939.48 and for cowpea seed production was Rs 40038.43. The average per hectare green fodder production was 382.50 quintals in cowpea fodder production while in cowpea seed production, the green fodder yield was 202.50 quintals. In cowpea seed production, the average of $571.00 \mathrm{~kg}$ of ungraded seed was produced and from it, total quality seed received was $529.13 \mathrm{~kg}$ (92.6\% of ungraded seed). The average per hectare total return and net return in cowpea fodder production was Rs 38250 and Rs 18310.52 respectively, and in case of cowpea seed production $\mathrm{Rs} 59218.26$ and $\mathrm{Rs} 19179.83$ respectively. The benefit cost ratio in cowpea fodder production was 1.92 and in case of cowpea seed production was as 1.49. In cowpea fodder production, the cost of fodder production per quintal was found as Rs 52. It is the cost at which the farmers use the fodder for their livestock. While the cost of cowpea seed production per $\mathrm{kg}$ was found as Rs 36.74 when farmer is able to utilize the byproducts and $\mathbf{R s} 75.76$ when farmer is not utilizing the byproducts.
\end{abstract}

KEYWORDS: Economics, Cowpea Fodder and Seed Production, Cost of Cultivation, Seed Processing, Benefit- Cost Ratio \& Comparative Analysis

Received: May 15, 2017; Accepted: Jun 14, 2017; Published: Jun 29, 2017; Paper Id.: IJASRAUG201711

\section{INTRODUCTION}

It is an annual or perennial, bushy herb grown for both fodder and grain (as pulse). The production of cowpea depends largely on the environmental factors, cropping systems and soil type of the location (Sebetha and Modi, 2016). In general, it can provide 350 - 420 quintals of green fodder and about 11-15 quintals of seed. For providing balance fodder, cowpea is an important leguminous fodder crop and grown alone or in combination with other graminacious fodder crops in Kharif/Zaid season crops. It also fixes nitrogen in the soil and it nourishes the soil fertility. It is best suited to moderately humid areas of tropics and subtropics and up to height of $1500 \mathrm{~m}$ from sea level. It is grown for fodder and its grain is used as pulse in human diet (Bubenheim et al., 1990). The feeding value of cowpea forage is high and comparable to Lucerne (Mukherjee and Maiti 2009). It is suitable for green feeding, hay making and can also be used in ensiling in mixtures with sorghum or maize. It can also be used as green manure crop and as green cover crop in plantation crops.

For fodder purpose, its seed gets huge demand in the market. The timely availability of seed to the 
farmers gets the full potential of its fodder. Thus, assurance of quality seed assures the high green fodder yield also. Thus, the study has been initiated to make a comparative economics of cowpea fodder production and cowpea seed production for providing an opportunity to farmers/seed companies/ dairy owners for taking the advantage of two different enterprises.

\section{MATERIAL AND METHODS}

The data for Cowpea fodder production are for year 2011-12 and 2012-13 from 10 farmers fields in Datia, M.P. with the commercial variety EC4216. The fields were prepared first by harrowing /cultivator for good tilth and seed were sown manually/by using seed drill in line at $30 \mathrm{~cm}$ distance. Seed rate was taken as $40 \mathrm{~kg}$ per hectare and FYM was mixed in soil before sowing and basal dose of $80 \mathrm{~kg}$ DAP was provided. Fodder crop was harvested after 60-80 days of sowing. Crop were grown in Kharif season and rain fed. Rate of green fodder was estimated as Rs 100/quintal.

For cowpea seed production, analysis of cowpea was done at IGFRI Jhansi with the commercial variety EC4216 in the year 2010-11 and 2012-13. 3 fields were selected for the study in both seasons. The fields were prepared first by one cross harrowing followed by cultivator for good tilth. After making strips, the seed was sown by seed drill.

The seed rate was taken as $12.5 \mathrm{~kg}$ per hectare and $100 \mathrm{~kg}$ DAP was applied as basal. In season 1 ( 2010-11), irrigations were not required as rain was sufficient and irrigations were required in season 2 ( 2012-13) and provided by diesel tube well as and when required. One Weeding and two rouging were done manually. No fodder cuttings were taken. 3-4 picking of pods were made before harvesting. At the time of harvesting the fodder was also green. The pods were threshed with the help of thresher.

The ungraded produce was then processed through processing machine and pure seed was produced. The variable cost and fixed cost were calculated for different machines used and multiplied with hours for which they used to find the expenditures incurred on them. The labour rate was taken as Rs 128 per manday of 8 hours in 2010 and Rs 150 per day in 2012. The rate of green fodder was taken as Rs 100 per quintal and for dry pods straw received from threshing was calculated as Rs 300 per quintal. The rate for pure seed was considered as Rs 70 per kilogram in year 2010 and Rs 75 per kilogram in year 2012. The total working capital shows the total variable cost incurred on various operations. The addition of all the fixed cost, overhead cost and rental value of land gives the total fixed cost. The rental value of land was considered as that prevailing in the locality. The management and risk was considered as ten percent of total variable and fixed cost. The cost of cultivation data were calculated for every stage of crop growth (Kumar 2013).

\section{RESULTS AND DISCUSSIONS}

Operation wise cost of production is calculated over individual farms and then the data are converted into per hectare basis and presented in Table 1 and figure 1. In case of fodder production, it was found that highest cost was incurred in fodder cutting (Harvesting) as Rs 4479.17 (22.46\% of total cost) and followed by manures and fertilizers as Rs 4365.92 (22.90\% of total cost). The variable cost was Rs 12776.02 per hectare ( $64.07 \%$ of total cost) and the fixed cost was $26.84 \%$ of total cost. The total cost of cowpea fodder production was found as Rs 19939.48 per hectare.

While in case of cowpea seed production, the pod picking has incurred the highest expenditure that was Rs 7380 ( $18.85 \%$ of total cost) followed by weeding $(10.22 \%$ of total cost). Three pickings were made for pods. Two rougings are performed and the average cost incurred on that is Rs 2156.52. The total expenditure incurred on harvesting is Rs 4100 which is done manually by sickle. The total variable cost is found as Rs 28854.49 . The rental value is taken as Rs 5000 per 
hectare as this is found prevalent in the locality. The total fixed cost is found as Rs 5187.50 per hectare. The share of variable cost and fixed cost in total cost is 73.71 percent and 13.25 percent respectively. The average total cost is found as Rs 39148.29 per hectare (Table 1).

The input/item wise numbers and cost distribution is analyzed and presented in table 3 . The total labour mandays used in cowpea fodder production was 32.75 per hectare while in cowpea seed production, the total labour mandays used was 144.60. The higher mandays were involved in cowpea seed production was due to numbers of operations that involved human labour as weeding, rouging, picking and harvesting. The percentage expenditure made on labour was also found highest in both fodder production and seed production which was 24.41 and 50.74 percent respectively. This also confirms the findings of Langyintuo, A.S., et al., 2003 that labour often accounts as highest cost in the total cost of production In fodder production, the crop was rainfed and no irrigation was required (Table 2).

Per hectare economics of cowpea seed processing is shown in Table 3. The total ungraded seed produced was $571.00 \mathrm{~kg}$ per hectare. After processing it, the net graded seed was found as $529.13 \mathrm{~kg}$ and some other byproducts were also received as waste seed $(33.40 \mathrm{~kg})$ and straw $(8.29 \mathrm{~kg})$ (Table 3$)$.

The return received from processed seed and other by products from field and processing unit in case of seed production are presented in table 4 . The total cost involved in seed production was Rs 40038.43 per hectare and total return from various items as graded seed, waste seed, and straw from processing and green fodder from harvesting green crop was Rs 59218.26 per hectare (Table 4).

The comparative cost and return analysis for cowpea fodder and seed production are shown in Table 5. It is found that total cost incurred in fodder production was Rs 19939.48 and cowpea seed production was Rs 40038.43 per hectare. Per hectare green fodder production was 382.50 quintals in cowpea fodder production, while in cowpea seed production, it was 202.5 quintals. The value of green fodder is estimated at Rs 100 per quintals ( the rate at which fodder is sold in limited urban fodder markets). Most of the fodder is produced by the farmers for their livestock consumption only. The gross return was Rs 38250 per hectare in cowpea fodder production, while it is Rs 59218.26 in case of cowpea seed production. The net return per hectare was found as Rs 18310.52 in cowpea fodder production and Rs 19179.83. The benefit cost ration in case of cowpea fodder production was 1.92 and in case of cowpea seed production was 1.49. The cost of one quintal fodder production was found as Rs 52. This is the cost at which the farmer uses the green fodder for its livestock. If there is market for green fodder, the farmer is able to sell green fodder up to Rs 100 per quintal and receives the significant margin over the cost. In case of seed production, the cost per $\mathrm{kg}$ of graded seed production was Rs 36.74 when by product were also utilized and Rs 75.76 per kg only pure seed was used and no by products (Table 5).

Thus, it is clear from the study that if there is market for the sale of green fodder, the Cowpea seed production is highly profitable. The price of Cowpea seed varies in the market form Rs 70 per kilogram to Rs 110 per kilogram, the farmers can take the advantage of high price during the sowing season, so they are advised to sell the seed during the sowing season. The seed production of leguminous crops encourages the farmers as it ensures the higher profit and quality seed for sowing in next season. This also confirms the findings of Govind Pal et al 2016.

\section{CONCLUSIONS}

From the finding, it is concluded that cost of cowpea fodder production is about half the cost of cowpea seed production. However, the cowpea seed production leads to more employment of resources and bringing the quality seed for 
next season reduces the farmers' dependability on uncertain market. As the cowpea seed size is larger, we get lesser rejected seed during processing (7.4\% only) and good quantity of graded seed is obtained (92.6\%). The area under cowpea fodder and demand for quality cowpea seed are complementary in nature. The health of livestock will be good and also the production from them will be higher. This will increase the demand for quality cowpea seed. The farmers can also leave a small area for cowpea seed production to reduce the uncertainty of seed availability in next season and also receive the seed at half of the cost of seed in the market.

\section{ACKNOWLEDGEMENTS}

Authors are grateful to Director, IGFRI for providing necessary research facilities for this study.

\section{REFERENCES}

1. Bubenheim D. L, C. A. Mitchell and S. S. Nielsen (1990) Utility of cowpea foliage in crop production for space. In: J. Janick and J. E. Simon (Ed.). Advances in new crops. Timber Press. 535-538.

2. Erick Sebetha and Albert Modi ( 2016) Cowpea yield under the influence of cropping system, location and nitrogen fertilization. Legume Research-An International Journal. Volume 39 Issue 3 (October 2016): 435-441

3. Govind Pal, Radhika C., R. K. Singh, Udaya Bhaskar K., H. Ram and S. Rajendra Prasad (2016) Comparative economics of seed production vis - à - vis grainproduction of pigeonpea in Karnataka, India. Legume Research-An International Journal. Volume 39 Issue 5 (October 2016): 806-809

4. Langyintuo, A. S., Lowenberg-DeBoer, J., Faye, M., Lambert, D., Ibro, G., Moussa, B., Kergna, A., Kushwaha, S., Musa, S \& Ntoukam, G. (2003) Cowpea supply and demand in West and Central Africa. Field Crop Research 82 (2003): 215-231.

5. Mukherjee A. K., and Maiti, S. M. (2009) Annual-leguminous summer crop; Cowpea, Book on Forage Crops, Production and Conservation, Kalyani Publishers 2009 : 86-92

6. Kumar, V., Satyapriya, Singh, M. and Pandey, H. C. ( 2013) Business in Producing the Quality Seed of Dinanath Grass (Pennisetum Pedicellatum Trin.). Progressive agriculture- An internaltional Journal. Vol 13(2): 178-182.

\section{APPENDICES}

Table 1: Operation Wise Cost Expenses (Rs/ Hectare)

\begin{tabular}{|l|c|c|c|c|}
\hline \multicolumn{1}{|c|}{ Operations } & $\begin{array}{c}\text { Fodder Crop } \\
\text { (Average) }\end{array}$ & Percent & Fodder Seed (Average) & Percent \\
\hline Field preparation & 1143.38 & 5.73 & 1054.38 & 2.69 \\
\hline Sowing & 2415.44 & 12.11 & 867.34 & 2.22 \\
\hline Manures and fertilisers & 4365.92 & 21.90 & 4258.15 & 10.88 \\
\hline Irrigation & - & 0.00 & 3366.37 & 8.6 \\
\hline Weeding & - & 0.00 & 4000 & 10.22 \\
\hline Rouging & - & 0.00 & 2156.52 & 5.51 \\
\hline Pod picking & - & & 7380 & 18.85 \\
\hline Harvesting and pooling & 4479.17 & 22.46 & 4100 & 10.47 \\
\hline Threshing & - & 0.00 & 831.31 & 2.12 \\
\hline Total Working capital & 12403.9 & 62.21 & 28014.07 & 71.56 \\
\hline Total variable cost & 12776.02 & 64.07 & 28854.49 & 73.71 \\
\hline Rental value of land & 5000 & 25.08 & 5000 & 12.77 \\
\hline Total fixed cost & 5350.78 & 26.84 & 5187.5 & 13.25 \\
\hline Total variable cost + Total & 18126.8 & 90.91 & 34041.99 & 86.96 \\
Fixed cost, Rs & 1812.68 & 9.09 & 5106.3 & 13.04 \\
\hline Management \& Risk & $\mathbf{1 9 9 3 9 . 4 8}$ & $\mathbf{1 0 0 . 0 0}$ & $\mathbf{3 9 1 4 8 . 2 9}$ & $\mathbf{1 0 0}$ \\
\hline \multicolumn{2}{|c|}{ Total Cost } & & &
\end{tabular}


Table 2: Item Wise Cost Distribution in Cowpea Fodder and Seed Production (Per Hectare)

\begin{tabular}{|c|c|c|c|c|}
\hline Particulars & $\begin{array}{l}\text { Cowpea Fodder } \\
\text { Production }\end{array}$ & Percent & $\begin{array}{c}\text { Cowpea } \\
\text { Seed } \\
\text { Production } \\
\end{array}$ & Percent \\
\hline \multicolumn{5}{|l|}{ Draft power } \\
\hline Draft power, hours & 2.40 & & 6.94 & \\
\hline Draft power cost, Rs & 995.36 & 4.99 & 1573.99 & 4.02 \\
\hline \multicolumn{5}{|l|}{ Labour power } \\
\hline Total mandays, Numbers & 32.75 & -- & 144.60 & \\
\hline Total Labour cost, Rs & 4867.62 & 24.41 & 19862.09 & 50.74 \\
\hline Seed cost, Rs & 2250 & 11.28 & 593.47 & 1.52 \\
\hline Manures and Fertilizers, Rs & 4290.91 & 21.52 & 4018.15 & 10.26 \\
\hline Irrigation & - & 0.00 & & \\
\hline Tube well hours, Numbers & - & 0.00 & 42.21 & \\
\hline Tube well cost, Rs & - & 0.00 & 1966.37 & 5.02 \\
\hline Plant protection chemicals, Rs & - & 0.00 & 0.00 & 0.00 \\
\hline Total Working capital, Rs & 12403.9 & 62.21 & 28014.07 & 71.56 \\
\hline Interest on WC, Rs & 372.11 & 1.87 & 840.42 & 2.15 \\
\hline Total variable cost, $\mathrm{Rs}$ & 12776.02 & 64.07 & 28854.49 & 73.71 \\
\hline Fixed and other overhead cost, Rs & 350.77 & 1.76 & 187.50 & 0.48 \\
\hline Rental value of land, Rs & 5000 & 25.08 & 5000.00 & 12.77 \\
\hline Total fixed cost, Rs & 5350.77 & 26.84 & 5187.50 & 13.25 \\
\hline TVC+ TFC, Rs & 18126.8 & 90.91 & 34041.99 & 86.96 \\
\hline management \& risk, Rs & 1812.68 & 9.09 & 5106.30 & 13.04 \\
\hline Total Cost, Rs & 19939.48 & 100.00 & 39148.29 & 100.00 \\
\hline
\end{tabular}

Table 3: Economics of Cowpea Seed Processing (Per ha)

\begin{tabular}{|l|c|}
\hline \multicolumn{1}{|c|}{ Items } & Average \\
\hline Ungraded, Kg & 571.00 \\
\hline Rate $(\mathrm{Rs} / \mathrm{kg})$ & 65.99 \\
\hline Value, $\mathrm{Rs}$ & 37693.70 \\
\hline Post harvest cost,Rs & 890.14 \\
\hline Total cost,Rs & 38583.85 \\
\hline TFL seed, kg & 529.13 \\
\hline Rate, Rs/kg & 72.50 \\
\hline Value, Rs & 38375.16 \\
\hline waste seed, kg & 33.40 \\
\hline Rate, $(\mathrm{Rs} / \mathrm{kg})$ & 6.00 \\
\hline Value, Rs & 200.40 \\
\hline straw, kg & 8.29 \\
\hline Rate, $(\mathrm{Rs} / \mathrm{kg})$ & 1.00 \\
\hline Value, Rs & 8.29 \\
\hline Total Returns, Rs & $\mathbf{3 8 5 8 3 . 8 5}$ \\
\hline
\end{tabular}

Table 4: Total Cost and Return from Processed Seed (Per Hectare)

\begin{tabular}{|l|c|}
\hline \multicolumn{1}{|c|}{ Particulars } & Average \\
\hline $\begin{array}{l}\text { Cost of cultivation, } \\
\text { Rs }\end{array}$ & 39148.29 \\
\hline Processing & 890.14 \\
\hline Total cost & 40038.43 \\
\hline TFL seed, kg & 529.13 \\
\hline Rate/kg $/ \mathrm{kg}$ & 72.50 \\
\hline Value & 38375.16 \\
\hline waste seed, kg & 33.40 \\
\hline Rate/kg & 6.00 \\
\hline
\end{tabular}




\begin{tabular}{|l|c|}
\hline \multicolumn{2}{|c|}{ Table 4: Cont'd } \\
\hline Value & 200.40 \\
\hline straw, kg & 392.70 \\
\hline Rate/kg & 1.00 \\
\hline Value & 392.70 \\
\hline green fodder, kg & 20250.00 \\
\hline Rate/kg & 1.00 \\
\hline Value & 20250.00 \\
\hline $\begin{array}{c}\text { Total Return from } \\
\text { Production, Rs }\end{array}$ & $\mathbf{5 9 2 1 8 . 2 6}$ \\
\hline
\end{tabular}

Table 5: Cost and Return Analysis for Cowpea ( EC4216) Fodder and Seed Production ( Per Hectare)

\begin{tabular}{|l|c|c|}
\hline \multicolumn{1}{|c|}{ Parameters } & $\begin{array}{c}\text { Average for Green } \\
\text { Fodder Production }\end{array}$ & $\begin{array}{c}\text { Average for } \\
\text { Graded Seed } \\
\text { Production }\end{array}$ \\
\hline Total cost, (Rs) & 19939.48 & 40038.43 \\
\hline Green fodder, (qtl.) & 382.50 & 202.5 \\
\hline Rate (Rs/qtl.) & 100.00 & 100.00 \\
\hline TFL seed, kg & --- & 529.13 \\
\hline Rate for TFL seed, (Rs /kg) & --- & 72.50 \\
\hline Gross return, (Rs) & 38250.00 & 59218.26 \\
\hline Net return, (Rs) & 18310.52 & 19179.83 \\
\hline Benefit :Cost ratio & 1.92 & 1.49 \\
\hline $\begin{array}{l}\text { Cost of green fodder/pure seed } \\
\text { ( Rs/quintal) }\end{array}$ & $\mathbf{5 2 . 0 0}$ & $\mathbf{3 6 . 7 4}$ \\
\hline Cost of pure seed ( Rs/kg) & & $\mathbf{7 5 . 7 6}$ \\
\hline $\begin{array}{l}\text { Cost of graded seed when only } \\
\text { main product is considered } \\
\text { (Rs/kg.) }\end{array}$ & -- & \\
\hline
\end{tabular}

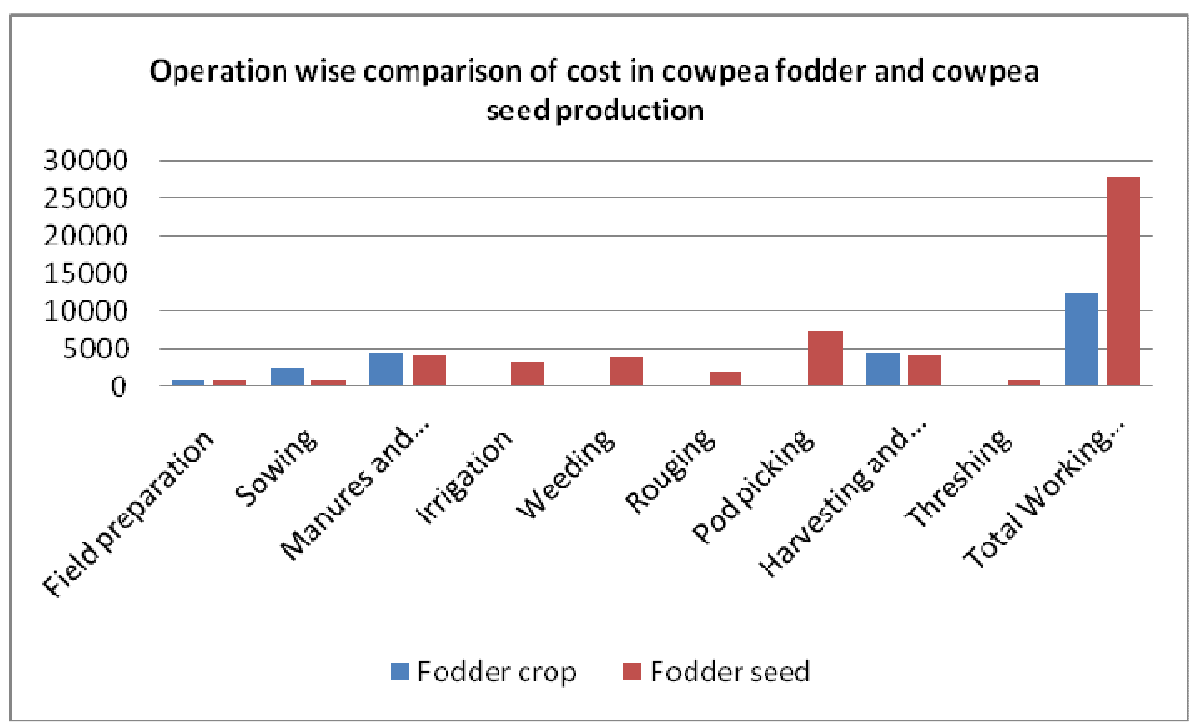

Figure 1: Operation Wise Comparison of Cost in Cowpea Fodder and Cowpea Seed Production 